Key Words:

Electrolysis

Hydrogen

Hybrid Sulfur

Retention: Permanent

\title{
Baseline Membrane Selection and Characterization for an SDE
}

\author{
H. R. Colon-Mercado \\ D. T. Hobbs
}

APRIL 2007

Savannah River National Laboratory

Washington Savannah River Company

Savannah River Site

Aiken, SC 29808

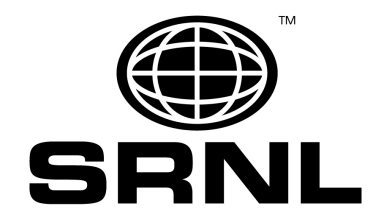




\section{DISCLAIMER}

This report was prepared as an account of work sponsored by an agency of the United States Government. Neither the United States Government nor any agency thereof, nor any of their employees, nor any of their contractors, subcontractors or their employees, makes any warranty, express or implied, or assumes any legal liability or responsibility for the accuracy, completeness, or any third party's use or the results of such use of any information, apparatus, product, or process disclosed, or represents that its use would not infringe privately owned rights. Reference herein to any specific commercial product, process, or service by trade name, trademark, manufacturer, or otherwise, does not necessarily constitute or imply its endorsement, recommendation, or favoring by the United States Government or any agency thereof or its contractors or subcontractors. The views and opinions of authors expressed herein do not necessarily state or reflect those of the United States Government or any agency thereof.

\section{Printed in the United States of America}

Prepared For U.S. Department of Energy 
Key Words:

Electrolysis

Hydrogen

Hybrid Sulfur

Retention: Permanent

\title{
Baseline Membrane Selection and Characterization for an SDE
}

\author{
H. R. Colon-Mercado \\ D. T. Hobbs
}

APRIL 2007

Savannah River National Laboratory

Washington Savannah River Company

Savannah River Site

Aiken, SC 29808

Prepared for the U.S. Department of Energy Under

Contract Number DE-AC09-96SR18500

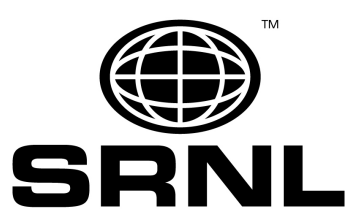




\section{REVIEWS AND APPROVALS}

$\overline{\text { H. R. Colon-Mercado, Co-author, Energy Security }}$ Date

D. T. Hobbs, Co-author, Process Chemistry and Science Date

W. A. Summers, Manager, Energy Security

Date

- ii - 


\section{TABLE OF CONTENTS}

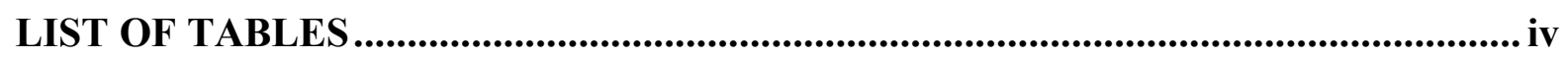

LIST OF FIGURES …............................................................................................................

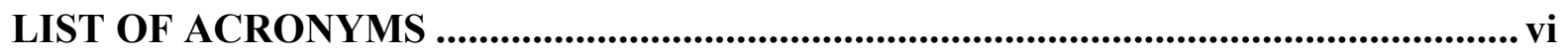

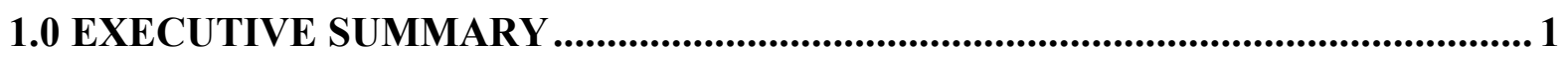

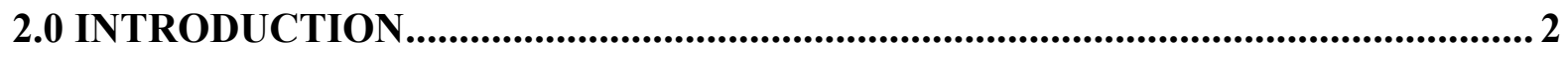

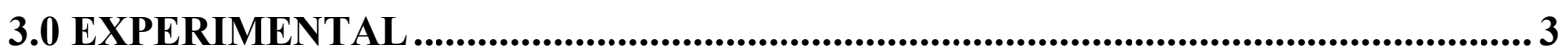

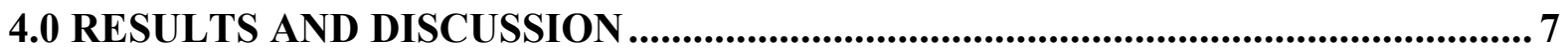

5.0 CONCLUSION AND RECOMMENDATIONS........................................................... 17

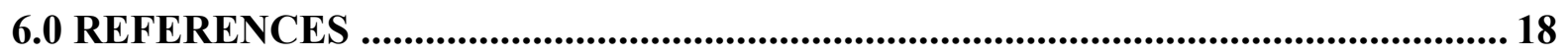




\section{LIST OF TABLES}

Table 1. Evaluated commercial membranes $\ldots \ldots \ldots \ldots \ldots \ldots \ldots \ldots \ldots \ldots \ldots \ldots \ldots \ldots \ldots \ldots . . \ldots \ldots \ldots$

Table 2. Evaluated experimental membranes .........................................4

Table 3. $\mathrm{SO}_{2}$ transport coefficient through the tested membranes immersed in 30 wt.\% and 50 wt.\% $\mathrm{H}_{2} \mathrm{SO}_{4}$ saturated with $\mathrm{SO}_{2}$ at room temperature. Working electrode set at $1040 \mathrm{mV}$ vs. SHE Comparison of diffusion coefficient and ionic resistance in evaluated membranes.........................................13 


\section{LIST OF FIGURES}

Figure 1. Simplified schematic of the SO2 transport characterization cell..............4

Figure 2. Simplified schematic of the ionic conductivity characterization cell...........5

Figure 3. $\mathrm{SO}_{2}$ transport through PFSA membranes immersed in (a) 30 wt.\% and (b) 50 wt.\% $\mathrm{H}_{2} \mathrm{SO}_{4}$ saturated with $\mathrm{SO}_{2}$ at room temperature. Working electrode set at $1040 \mathrm{mV}$ vs. SHE..........................................9

Figure 4. $\mathrm{SO}_{2}$ transport through commercial membranes immersed in (a) $30 \mathrm{wt} \%$ and (b) $50 \mathrm{wt} \% \mathrm{H}_{2} \mathrm{SO}_{4}$ saturated with $\mathrm{SO}_{2}$ at different temperatures. Working electrode set at $1040 \mathrm{mV}$ vs. SHE............................................11

Figure 5: $\mathrm{SO}_{2}$ transport through experimental membranes immersed in 30 wt.\% $\mathrm{H}_{2} \mathrm{SO}_{4}$ saturated with $\mathrm{SO}_{2}$ at room temperature. Working electrode set at $1040 \mathrm{mV}$ vs. SHE.......................................................12

Figure 6: Typical behavior representing the effect of an applied current across the membrane on the $\mathrm{SO}_{2}$ transport through a cationic membrane immersed in $30 \mathrm{wt} \% \mathrm{H}_{2} \mathrm{SO}_{4}$ saturated with $\mathrm{SO}_{2}$ at room temperature. Working electrode set at $1040 \mathrm{mV}$ vs. SHE....................................................14

Figure 7: Ion conductivity of the membrane samples as a function of temperature and acid concentration for (a) fluorocarbon type membranes and (b) hydrocarbon type membranes.............................................16 


\section{LIST OF ACRONYMS}

$\begin{array}{ll}\text { BAS } & \text { Bioanalytical Systems } \\ \text { DI-water } & \text { Deionized water } \\ \text { DM } & \text { Direct Methanol } \\ \text { EIS } & \text { Electrochemical Impedance Spectroscopy } \\ \text { EW } & \text { Equivalent Weight } \\ \text { GES } & \text { Giner Electrochemical Systems } \\ \text { HyS } & \text { Hybrid Sulfur } \\ \text { MEA } & \text { Membrane Electrode Assembly } \\ \text { OPM } & \text { Oxford Performance Materials } \\ \text { PA } & \text { Phosphoric acid } \\ \text { PBI } & \text { Poly-Benzimidazole } \\ \text { PEM } & \text { Proton Exchange Membrane and Polymer Electrolyte Membrane } \\ \text { PEMFC } & \text { Polymer Electrolyte Membrane Fuel Cell } \\ \text { PFSA } & \text { Perfluorinated Sulfonic Acid } \\ \text { RT } & \text { Room Temperature, } 25^{\circ} \text { C } \\ \text { SDAPP } & \text { Sulfonated Diels-Alder Polyphenylenes } \\ \text { SDE } & \text { Sulfur Dioxide-depolarized Electrolyzer } \\ \text { SHE } & \text { Standard Hydrogen Electrode } \\ \text { SNL } & \text { Sandia National Laboratory } \\ \text { SPEK } & \text { Sulfonated Poly-Etherketone } \\ \text { SPEKK } & \text { Sulfonated Poly-Etherketone-ketone } \\ \text { SRNL } & \text { Savannah River National Laboratory } \\ \text { SRS } & \text { Savannah River Site } \\ & \end{array}$




\subsection{EXECUTIVE SUMMARY}

Thermochemical processes are being developed to provide global-scale quantities of hydrogen. A variant on sulfur-based thermochemical cycles is the Hybrid Sulfur (HyS) Process which uses a sulfur dioxide depolarized electrolyzer (SDE) to produce the hydrogen. In FY05 and FY06, testing at the Savannah River National Laboratory (SRNL) explored a low temperature fuel cell design concept for the SDE. The advantages of this design concept include high electrochemical efficiency and small footprint that are crucial for successful implementation on a commercial scale.

A key component of the SDE is the ion conductive membrane through which protons produced at anode migrate to the cathode and react to produce hydrogen. An ideal membrane for the SDE should have both low ionic resistivity and low sulfur dioxide transport. These features allow the electrolyzer to perform at high currents with low potentials, along with preventing contamination of both the hydrogen output and poisoning of the catalysts involved. Another key component is the electrocatalyst material used for the anode and cathode. Good electrocatalysts should be chemically stable and have a low overpotential for the desired electrochemical reactions.

This report summarizes results from activities to evaluate commercial and experimental membranes for the SDE. Several different types of commercially-available membranes were analyzed for sulfur dioxide transport as a function of acid strength including perfluorinated sulfonic acid (PFSA), sulfonated poly-etherketone-ketone, and poly-benzimidazole (PBI) membranes. Experimental membranes from the sulfonated diels-alder polyphenylenes (SDAPP) and modified Nafion ${ }^{\circledR} 117$ were evaluated for $\mathrm{SO}_{2}$ transport as well. These membranes exhibited reduced transport coefficient for $\mathrm{SO}_{2}$ transport without the loss in ionic conductivity.

The use of Nafion ${ }^{\circledR}$ with EW 1100 is recommended for the present SDE testing due to the limited data regarding chemical and mechanical stability of experimental membranes,. Development of new composite membranes by incorporating metal particles or by forming multilayers between PFSA membranes and hydrocarbon membranes will provide methods that will meet the SDE targets $\left(\mathrm{SO}_{2}\right.$ transport reduction by a factor of 100$)$ while decreasing catalyst layer delamination and membrane resistivity. 


\subsection{INTRODUCTION}

Thermochemical processes are being developed to provide global-scale quantities of hydrogen. Among the thermochemical processes, water electrolysis offers several advantages over other production methods. However, the technology and energy inputs for the electrolysis process can make the production of hydrogen by this method expensive. Thermochemical water splitting cycles offer an alternate highly efficient route for the production of hydrogen [1]. Among the many possible thermochemical cycles for the production of hydrogen, the sulfur-based cycles lead the competition in overall energy efficiency.

A variant on sulfur-based thermochemical cycles is the Hybrid Sulfur (HyS) Process. The HyS cycle uses a sulfur dioxide-depolarized electrolyzer (SDE) to produce hydrogen. The electrolyzer oxidizes sulfur dioxide to form sulfuric acid at the anode [r1] and reduces protons to form hydrogen at the cathode [r2]. The overall electrochemical cell reaction consists of the production of $\mathrm{H}_{2} \mathrm{SO}_{4}$ and $\mathrm{H}_{2}$ [r3].

$$
\begin{gathered}
\mathrm{SO}_{2}+2 \mathrm{H}_{2} \mathrm{O} \rightarrow \mathrm{H}_{2} \mathrm{SO}_{4}+2 \mathrm{H}^{+}+2 e^{-} \\
2 \mathrm{H}^{+}+2 e^{-} \rightarrow \mathrm{H}_{2} \\
\mathrm{SO}_{2}+2 \mathrm{H}_{2} \mathrm{O} \rightarrow \mathrm{H}_{2} \mathrm{SO}_{4}+\mathrm{H}_{2}
\end{gathered}
$$

Original work on the development of a SDE featured a parallel-plate electrolyzer with a separator or membrane to keep the anolyte and catholyte compartments separate [2]. Since this work was completed in the early 1980s, significant advances have occurred in electrolyzer technology principally in the area of hydrogen fuel cells. Advanced hydrogen fuel cells employ proton conductive membranes with catalyst layers deposited on either side of the membrane, forming the respective anode and cathode of the electrochemical cell. The combination of membrane and electrode catalyst layers is referred to as the membrane electrode assembly or MEA.

We selected the fuel cell MEA design concept for the SDE in the HyS process [3]. The MEA concept provides a much smaller cell footprint than conventional parallel plate technology. The smaller footprint is a major benefit in scaling the electrolyzer to the size that will be required for commercial production. Key attributes of the SDE are high energy efficiency and long operating lifetime. To achieve high energy efficiency, the electrolyzer must exhibit rapid reaction kinetics at each electrode, little crossover of reagent and products across the membrane, and excellent chemical stability of each of the components to concentrated sulfuric acid solutions.

In this report we summarize the results from the characterization studies of the commercial and experimental membranes. The studies focus on evaluating commercially-available and experimental membranes for ionic resistance and sulfur dioxide transport characteristics at different acid concentrations and temperatures. 


\subsection{EXPERIMENTAL}

\subsection{MEMBRANE PREPARATION}

A list of the tested membranes is shown in Table 1 and Table 2. During the selection process of commercially available and experimental membranes, an array of thicknesses, equivalent weights (EWs), chemistry, and reinforcements were considered. Preparation procedures of the membranes before testing were conducted according to the supplier's recommendations. Commercial membranes include perfluorinated sulfonic acid (PFSA) membranes and nonfluorinated membranes such as Fumatech sulfonated poly-etherketone (SPEK), which were conditioned by washing in $0.5 \mathrm{M} \mathrm{H}_{2} \mathrm{SO}_{4}$ at $80{ }^{\circ} \mathrm{C}$ for one hour and rinsing in deionized water (DI-water) at $80{ }^{\circ} \mathrm{C}$ for another hour. Once treated, the membranes were stored in water until ready to use. Commercial Poly-benzimidazole type membranes (PBI) from Celtec and sulfonated poly-etherketone-ketone (SPEKK) from Oxford Performance Materials (OPM) were rinsed with water before use.

Table 2 shows the experimental membranes prepared exclusively to reduce the transport of inert species such as dissolved $\mathrm{SO}_{2}$. The membranes include Sandia National Laboratory (SNL) hydrated sulfonated Diels-Alder polyphenylenes (SDAPP) and Giner Electrochemical Systems (GES) hydrated platinized Nafion 117. These membranes were used as received.

Table 1. Evaluated commercial membranes

\begin{tabular}{ccccc}
\hline \hline ID & Manufacturer & Classification & $\begin{array}{c}\text { Thickness } \\
(\mu \mathbf{m})\end{array}$ & $\begin{array}{c}\text { Equivalent } \\
\text { Weight } \\
\text { (g/eq.) }\end{array}$ \\
\hline Nafion $^{(B)} 117$ & DuPont & PFSA & 180 & 1100 \\
\hline Nafion $^{(B)} 112$ & DuPont & PFSA & 50 & 1100 \\
\hline F-1460 & Fumatech & PFSA & 60 & 1400 \\
\hline Celtec-V & PEMEAS & PBI with immobilize & 50 & ---- \\
\hline Celtec-L & PEMEAS & electrolyte & & ---- \\
\hline FKB & Fumatech & PEK & 80 & N/A \\
\hline OXPEKK & OPM & SPEK & 25 & 700 \\
\hline E-750 & Fumatech & SPEK & 50 & 50 \\
\hline \hline
\end{tabular}


Table 2. Evaluated experimental membranes

\begin{tabular}{cllcc}
\hline \hline ID & Manufacturer & Classification & $\begin{array}{c}\text { Thickness } \\
(\mu \mathbf{m})\end{array}$ & $\begin{array}{c}\text { Equivalent } \\
\text { Weight } \\
\text { (g/eq.) }\end{array}$ \\
\hline $\begin{array}{c}\text { Platinized } \\
\text { Nafion }{ }^{\circledR} 117\end{array}$ & GES & PFSA & 180 & 1100 \\
\hline SDAPP-2.2 & SNL & SDAPP & 50 & N/A \\
\hline SDAPP-1t & SNL & SDAPP & 50 & N/A \\
\hline SDAPP-4t & SNL & SDAPP & 25 & N/A \\
\hline SDAPP-1.6 & SNL & SDAPP & 76 & N/A \\
\hline \hline
\end{tabular}

\subsection{MEMBRANE CHARACTERIZATION}

The membrane $\mathrm{SO}_{2}$ transport was evaluated using a custom made permeation cell; a schematic of the cell is shown in Figure 1. The cell consists of two glass chambers joined by a Teflon ${ }^{\mathrm{TM}}$ bridge where the membrane is secured. During measurements both chambers were filled with the concentrated acid of interest and purged of oxygen by flowing nitrogen. A three electrode system, which included a silver-silver chloride reference electrode (Ag/AgCl, $196 \mathrm{mV}$ vs. standard hydrogen electrode (SHE)), a platinum flag as the counter electrode, and a platinum mesh as the working electrode, was used during measurements.

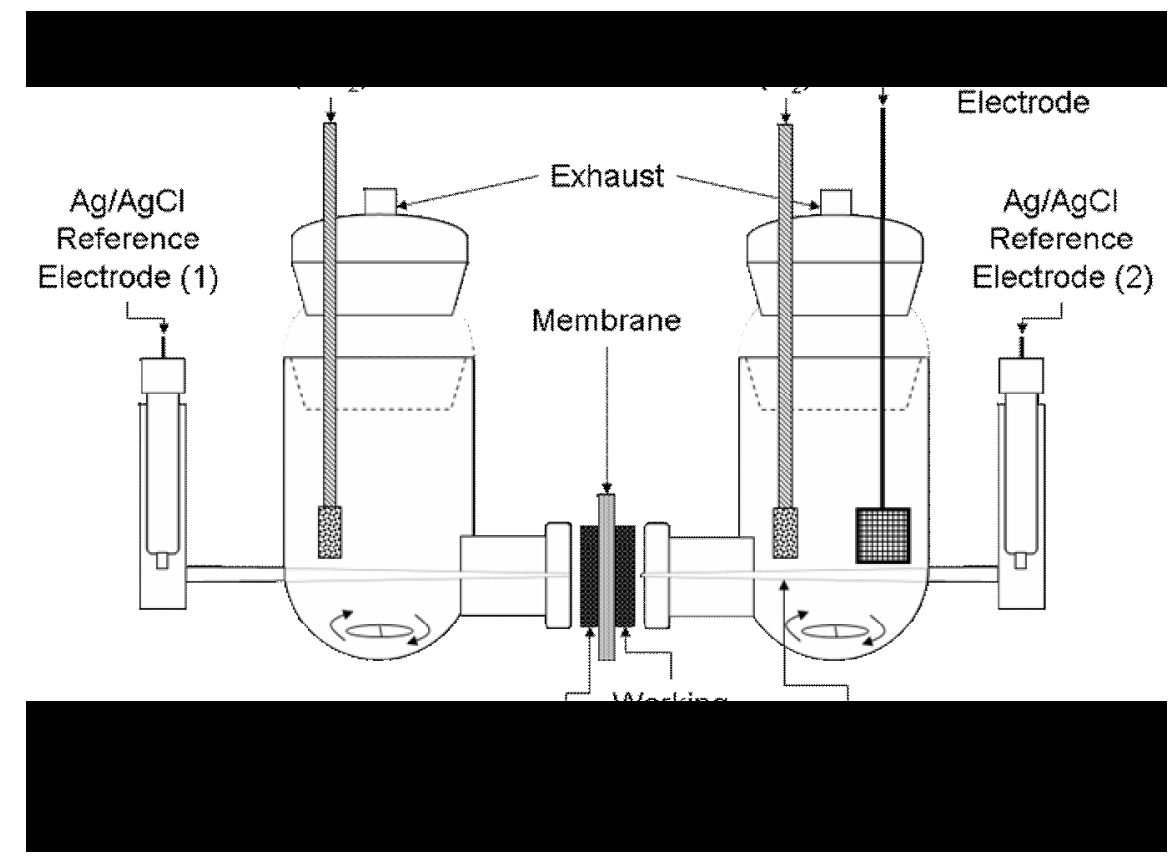

Figure 1. Simplified schematic of the $\mathrm{SO}_{2}$ transport characterization cell 
The $\mathrm{SO}_{2}$ transport was monitored by measuring the current as a function of time while a constant potential is applied. For the $\mathrm{SO}_{2}$ transport, the reference and working electrodes were rearranged in position (2). The cell was filled with $30 \mathrm{wt} \%$ or $50 \mathrm{wt} \% \mathrm{H}_{2} \mathrm{SO}_{4}$ and purged with $\mathrm{N}_{2}$. A constant potential of $1040 \mathrm{mV}$ vs. SHE was applied on the working electrode while the current was measured as a function of time. Once the background current became close to zero, the flowing of $\mathrm{SO}_{2}$ was started on the left chamber. The $\mathrm{SO}_{2}$ permeating through the membrane was oxidized to sulfuric acid by the working electrode. A Bioanalytical Systems (BAS) B/W electrochemical analyzer was used to measure the current responses as a function of time.

A variant of the SO2 transport experiment was performed in order to assess the sulfur dioxide transport under an applied potential. This experiments looks to evaluate the effect on the $\mathrm{SO}_{2}$ transport at conditions similar to the electrolyzer runs, where the membrane experiences a potential difference. During this experiment a second set of electrodes was immersed in the electrolyte solution. The electrodes were arranged so that the working electrode is on the side containing $\mathrm{SO}_{2}$ and the reference-counter electrode is on the side purged with $\mathrm{N}_{2}$. The experiment was carried out as before with the only difference being that once the $\mathrm{SO}_{2}$ transport reaches steady state, a current is applied to the system while measuring continuously the $\mathrm{SO}_{2}$ transport. The electrodes applying the current across the membrane are controlled with a PARSTAT 2273 system while the $\mathrm{SO}_{2}$ transport measurement is controlled with the BAS system.

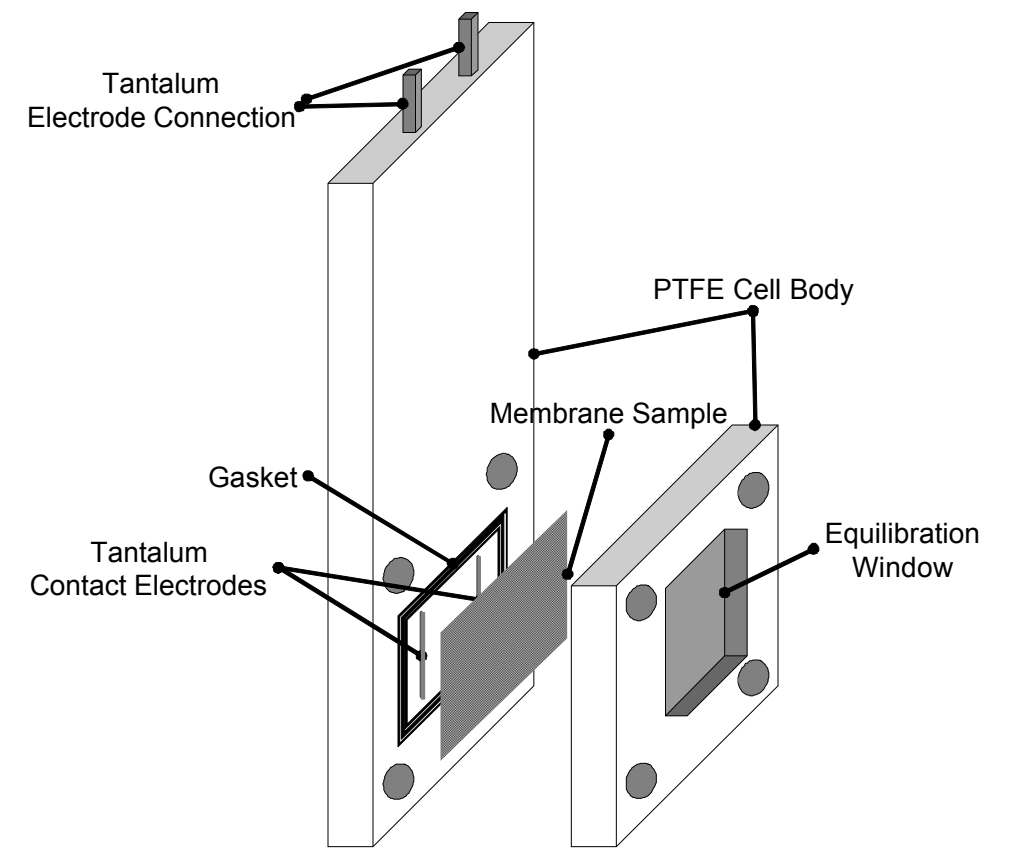

Figure 2. Simplified schematic of the ionic conductivity characterization cell

The Electrochemical Impedance Spectroscopy (EIS) technique was used to evaluate the ionic resistivity $(\rho)$ as a function of acid concentration. For this measurement an ionic conductivity cell was used, Figure 2 shows a simplified schematic of the cell. A two electrode system was used for the measurement. After allowing several minutes for the 
membrane to equilibrate, a $10 \mathrm{mV}$ vs. OCP (open circuit potential) sinusoidal voltage was imposed across the membrane at frequencies between $500 \mathrm{kHz}$ and $200 \mathrm{~Hz}$. The resulting response was plotted in the form of Nyquist plots. The resistance was calculated from the value of the real impedance when the imaginary response is zero. The resistivity was calculated with the following equation,

$$
\rho=\frac{Z_{\text {real }} A}{L}
$$

where ' $L$ ' is the thickness of the membrane, ' $A$ ' is the area available for proton conduction, and ' $Z_{\text {real }}$ ' is the real part of the impedance response when the imaginary impedance is zero. A PARSTAT 2273 potentiostat/frequency analyzer from Princeton Applied Research was used for this measurement. 


\subsection{RESULTS AND DISCUSSION}

\subsection{SULFUR DIOXIDE TRANSPORT AT REST CONDITIONS}

In a perfectly efficient $\mathrm{SDE}$, all of the $\mathrm{SO}_{2}$ is oxidized to sulfuric acid [r1]. In practice, the cell is not $100 \%$ efficient and some of the $\mathrm{SO}_{2}$ migrates from the anolyte side through the membrane into the catholyte side of the cell. Migration of the neutral $\mathrm{SO}_{2}$ species largely arises by diffusion driven by the concentration gradient from the anolyte to the catholyte. Upon reaching the cathode, $\mathrm{SO}_{2}$ can be reduced to produce sulfur and sulfides. Reduction of the $\mathrm{SO}_{2}$ decreases the electrical efficiency of the cell. The $\mathrm{SO}_{2}$ transport to the cathode not only affects the purity of the hydrogen being produced, but the long term effects of these impurities incorporated in the membrane, cathode catalyst, or diffusion layer are not yet known.

Thus, a separator with high ionic conductivity, low minimal $\mathrm{SO}_{2}$ transport, and long term stability is needed. The current design for the SDE is based on a polymer electrolyte membrane fuel cell (PEMFC). The Nafion ${ }^{\circledR}$ family of perfluorinated sulfonic acid membranes is an attractive candidate membrane due to its relatively high ionic conductivity and chemical stability in strong acid solutions. However, previous testing indicated fairly high $\mathrm{SO}_{2}$ transport across this membrane to the cathode.

A review of the literature revealed a number of commercially available membranes that may be suitable for use in the SDE. Table 1 provides the list of commercial membranes that were selected for testing the $\mathrm{SO}_{2}$ transport. The first group of membranes selected was the PFSA family membranes which have been developed for PEM fuel cells for operation at low temperatures $\left(80^{\circ} \mathrm{C}\right)$. The properties of the PFSA type membrane with an equivalent weight (EW) of 1100 is considered in this work as the baseline to which all other membranes were compared. Membranes developed for Direct Methanol (DM) fuel cells such as SPEKK and SPEK are studied in this work due to their improved properties to reduce the crossover of methanol and their ability to operate at higher temperatures (up to $140{ }^{\circ} \mathrm{C}$ ). Finally membranes originally developed for Phosphoric Acid (PA) fuel cells from the PBI family were selected for their ability to operate at temperatures up to $200{ }^{\circ} \mathrm{C}$ under dry conditions. Unlike the sulfonated type of membranes (PFSA, SPEKK or SPEK) that employ sulfonic acid groups to transport hydrated protons, these PBI membranes employ a hopping mechanism in which immobilized anions (such as PA) act as proton solvents and provide a path for rapid proton exchange. As a result, protons are conducted without the creation of water channels that transport water and other inert molecules. Table 2 provides the list of experimental membranes that are being develop to decrease the transport of neutral species such as $\mathrm{SO}_{2}$. The first membrane consists of the use of platinum nano-particles embedded in the pores of a Nafion ${ }^{\circledR} 117$ membrane to reduce the transport of neutral species. A similar approach has been considered for the development of methanol-blocking membranes without adverse effects on the proton conductivity [4]. The other set of membranes consist of SDAPP which provide a good proton conductivity with reduced water transport. 
The permeation rate of $\mathrm{SO}_{2}$ species through the membranes was monitored by an electrochemical technique (see experimental section). The flux profile contains three distinct regions. Initially, the currents are flat indicating that the system is building up $\mathrm{SO}_{2}$ concentration in the chamber and membrane. As $\mathrm{SO}_{2}$ passes through the membrane, it is oxidized by the working electrode resulting in a measurable permeation. The permeation current increases with time until steady-state conditions (i.e., third region) are reached and no change in the flux is observed. By assuming that all $\mathrm{SO}_{2}$ transported reacts according to [ $\mathrm{r} 1$ ] we can obtain the $\mathrm{SO}_{2}$ flux, $J_{\mathrm{SO}_{2}}$, from the electrical response using Faraday's Law,

$$
J_{\mathrm{SO}_{2}}=\frac{i}{n F}
$$

where ' $i$ ' is the current density in $\mathrm{A} / \mathrm{cm}^{2}$, ' $F$ ' is Faraday's constant $(96,487 \mathrm{C} /$ eq. $)$, and ' $n$ ' is the number of electrons transferred.

The effect of the acid concentration on the $\mathrm{SO}_{2}$ flux through the commercial membrane samples is observed in Figure 3. At low acid concentration, the $\mathrm{SO}_{2}$ transport is highest (see Figure 3a) and decreases when the acid concentration is increased from $30 \mathrm{wt} . \%$ to $50 \mathrm{wt} . \%$ (see Figure $3 b$ ). This behavior can be explained by the change in water concentration on the polymer matrix. At low acid concentrations the membrane hydration level is higher, as a result the polymer swells increasing the polymer pore diameter. As the acid concentration increases, the hydration level of the polymer decreases causing the polymer matrix and the pores to shrink. The shrinkage of the pores results in smaller channels that reduce the amount of inert species permeating through the water channels. Although beneficial in reducing the $\mathrm{SO}_{2}$ transport, the decrease in water also affects the proton transport resulting in a decrease in ionic conductivity. Such decrease in ionic conductivity as a function of acid concentration has been observed by Junginger et al. [5].

The dependence on the thickness on membranes with same polymer chemistry can be observed in the figure by comparing the flux through $\mathrm{Nafion}^{\circledR} 112$ and $\mathrm{Nafion}^{\circledR} 117$. As expected, N112 exhibited the highest flux followed by N117, which follows the order of thickness for the Nafion ${ }^{\circledR}$ membranes (see Table 1). The concentration of sulfonic acid groups (i.e., equivalent weight) in the membrane also affects the transport of sulfur dioxide. As observed above, when the membranes hydrate, especially PFSA polymers, water binds to the ionic groups to produce a fully separate phase with concentrated ionic domains. This domain contains channels where neutral species that dissolve in water can diffuse. As a consequence, a membrane with the same thickness but higher EW will transport less $\mathrm{SO}_{2}$ than a material with lower EW as the number of domains is decreased. The effect of the amount of conductive groups on the flux can be observed by comparing Nafion ${ }^{\circledR} 112(\mathrm{EW}=$ $1100 \mathrm{~g} / \mathrm{eq})$ and F-1460 (1400 g/eq). For the PFSA type membranes, the lowest flux is observed for F-1460 and followed by Nafion ${ }^{\circledR} 117$ (which the decrease in transport is attributed to the increase in thickness).

The backbone of the polymer also affects the properties of the polymer. For example, polymers form the SPEK family such as E-750, which have an EW of 700 have a much lower $\mathrm{SO}_{2}$ transport than a membrane from the PFSA family with a higher EW (such as 
Nafion ${ }^{\circledR} 112$ ). The main possible reason for the reduction of $\mathrm{SO}_{2}$ flux is the use of polymers with stiffer backbones that will prevent the phase separation and the formation of ionic acid domains [6]. Among the membranes tested, OXPEKK showed the lowest flux followed closely by the FKB and Celtec-L membranes.
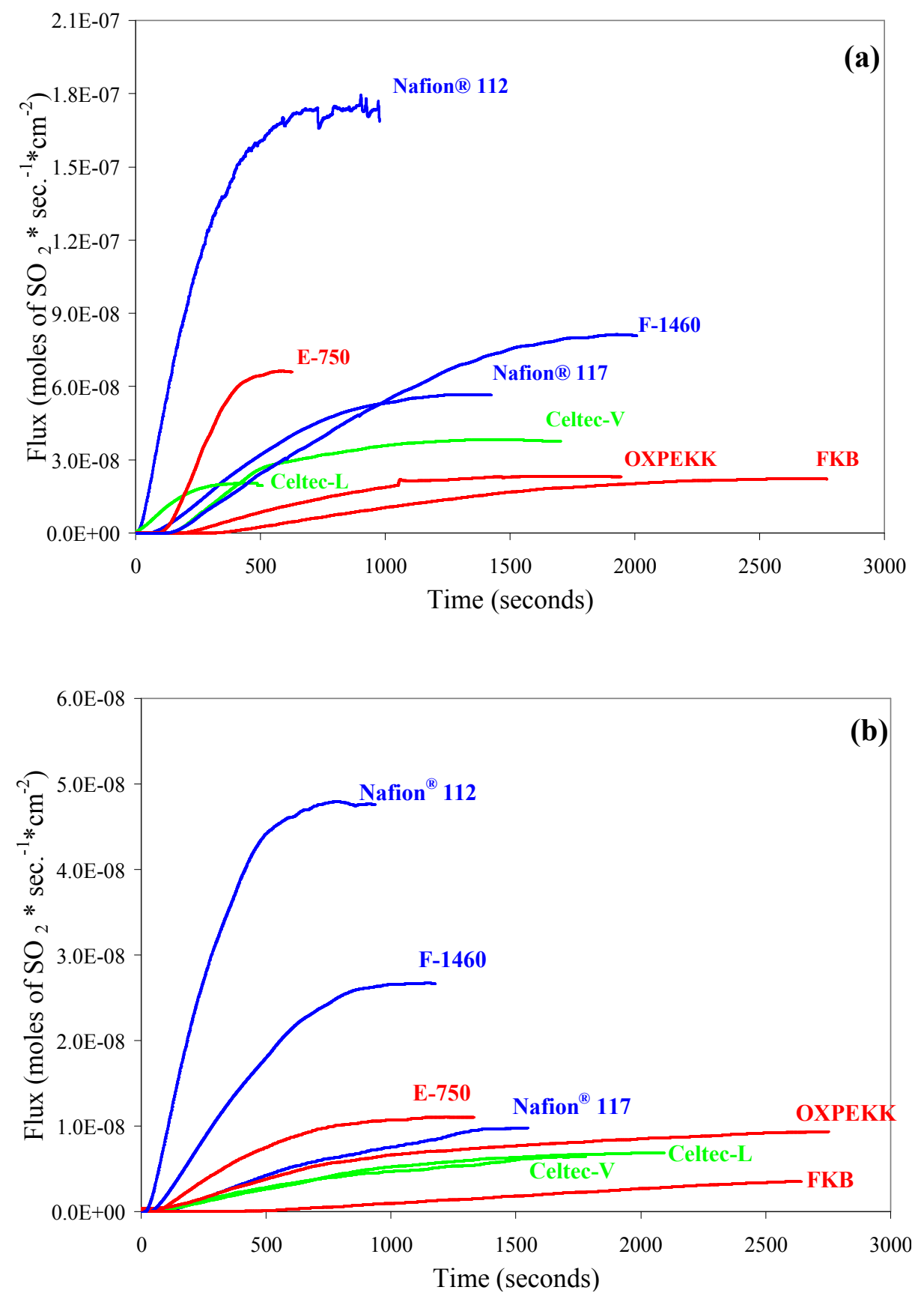

Figure 3. $\mathrm{SO}_{2}$ transport through commercial membranes immersed in (a) $30 \mathrm{wt} \%$ and (b) 50 wt.\% $\mathrm{H}_{2} \mathrm{SO}_{4}$ saturated with $\mathrm{SO}_{2}$ at room temperature. Working electrode set at $1040 \mathrm{mV}$ vs. SHE 
The effects of the acid concentration, membrane thickness, and temperature on the $\mathrm{SO}_{2}$ flux through Nafion ${ }^{\circledR}$ membrane samples are observed in Figure 4. At low temperature the $\mathrm{SO}_{2}$ transport is highest and it decreases as the temperature is increased (see Figure 4a). A similar behavior is observed when the acid concentration is increased from $30 \mathrm{wt} \%$ to $50 \mathrm{wt} \%$ (see Figure 4b).

At high temperatures the transport is expected to increase since the transport coefficient is dependent on temperature. However, the permeation cell is not pressurized and the solubility of $\mathrm{SO}_{2}$ in the acid solution decreases as the temperature is increased. In $30 \mathrm{wt} \%$ acid, the concentration of $\mathrm{SO}_{2}$ decreases from $1.090 \mathrm{M}$ at $25{ }^{\circ} \mathrm{C}$ to $0.4260 \mathrm{M}$ and $0.2122 \mathrm{M}$ at $50{ }^{\circ} \mathrm{C}$ and $70{ }^{\circ} \mathrm{C}$, respectively. A similar behavior is observed for the samples in $50 \mathrm{wt} \%$ acid solution with the exception of $\mathrm{N} 117$ where an anomaly is observed at $25{ }^{\circ} \mathrm{C}$. According to the previous data, the membrane tested at $25^{\circ} \mathrm{C}$ should have a $\mathrm{SO}_{2}$ transport higher than the sample tested at $50{ }^{\circ} \mathrm{C}$, but the recorded transport shows the opposite. This result will be repeated to corroborate the presented result.

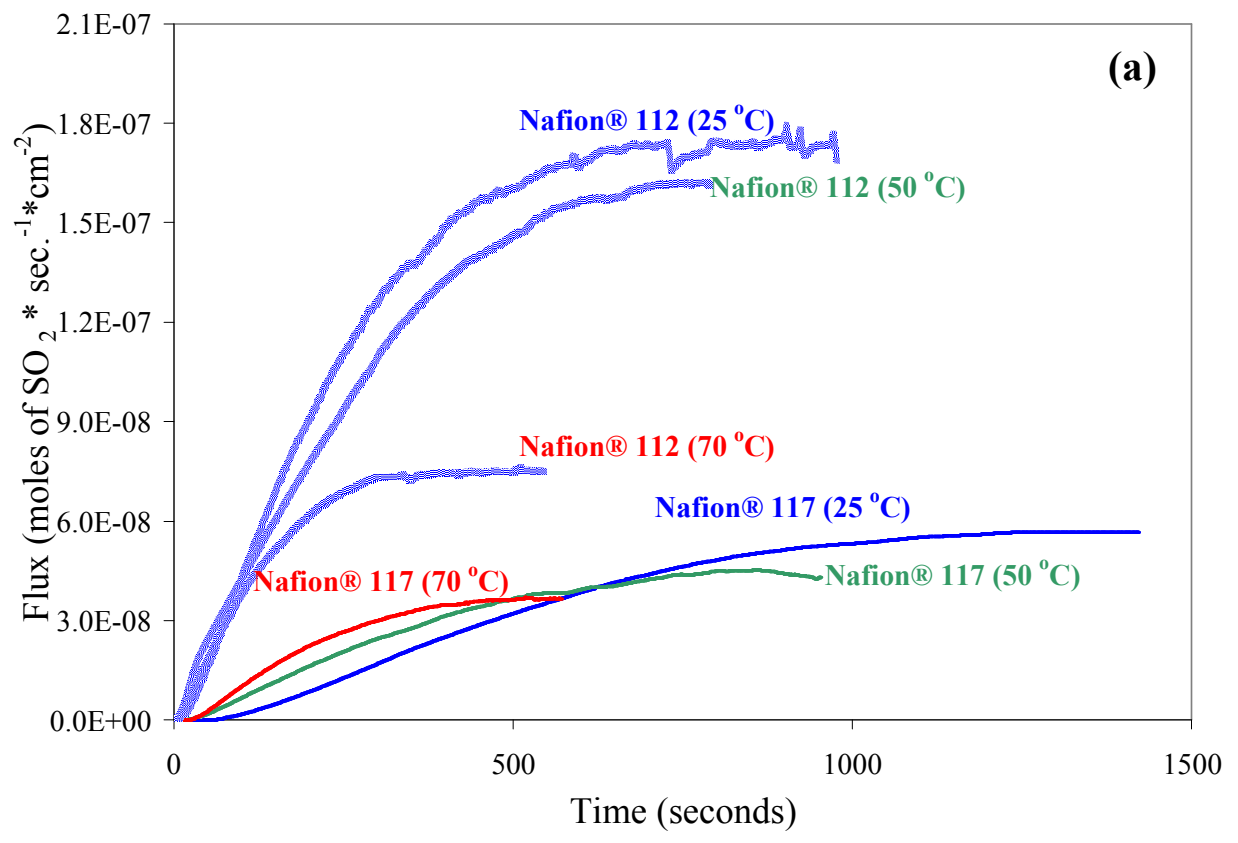




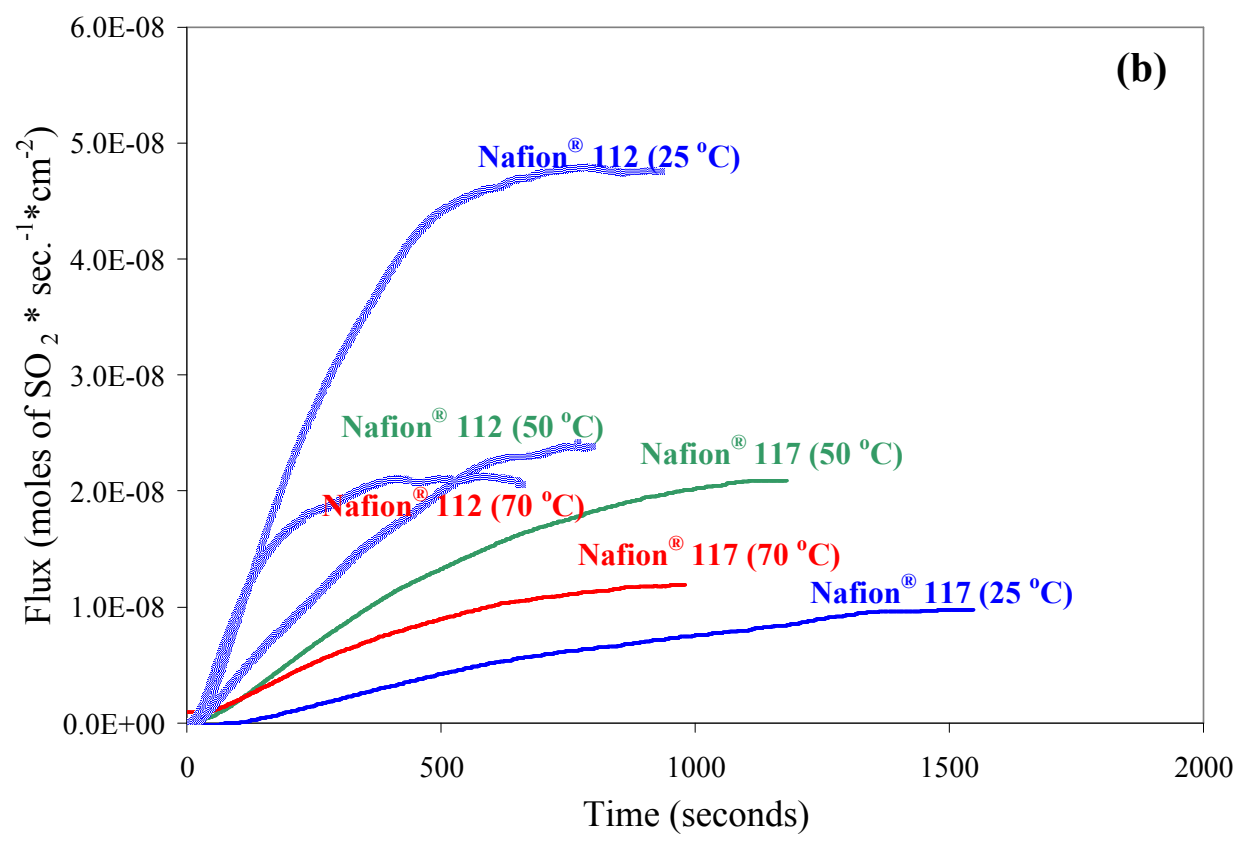

Figure 4. $\mathrm{SO}_{2}$ transport through commercial membranes immersed in (a) $30 \mathrm{wt} \%$ and (b) $50 \mathrm{wt}^{2} \mathrm{H}_{2} \mathrm{SO}_{4}$ saturated with $\mathrm{SO}_{2}$ at different temperatures. Working electrode set at $1040 \mathrm{mV}$ vs. SHE

Membrane modification techniques and new membranes are being developed worldwide in order to improve the properties of PFSA membranes currently used in fuel cells. At the moment these alternative membranes show superior properties such as high temperature operation and better barrier properties, but lack the high ionic conductivity of PFSA type membranes. At SNL new membranes are being developed with improved properties to target the needs of our SDE. The membranes developed are from the SDPPA family which contains a very strong backbone and good conductivity. At GES, PFSA membranes are being modified by embedding Pt nano-particles at the membrane pores to reduce the $\mathrm{SO}_{2}$ transport while keeping the ionic conductivity high. The results of these experimental membranes are plotted in Figure 5. 


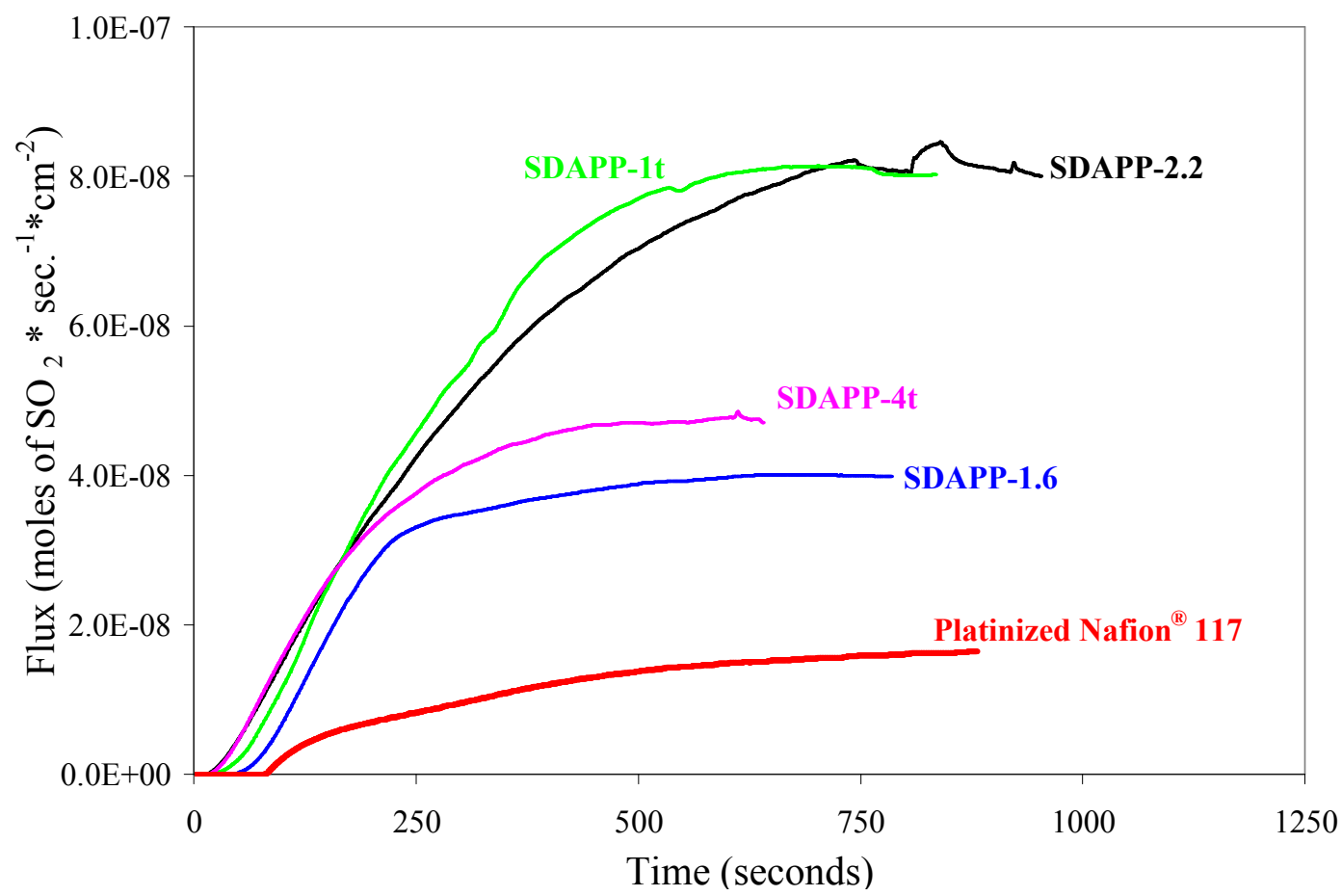

Figure 5: $\mathrm{SO}_{2}$ transport through experimental membranes immersed in 30 wt.\% $\mathrm{H}_{2} \mathrm{SO}_{4}$ saturated with $\mathrm{SO}_{2}$ at room temperature. Working electrode set at $1040 \mathrm{mV}$ vs. SHE

The $J_{\mathrm{SO}_{2}}$ through a membrane can be described by the modified Fick's law of diffusion, where the thickness, ' $L$ ', of the membrane and the transport coefficient, ' $D$ ', will play an important role on the flux. At steady state conditions and assuming that all $\mathrm{SO}_{2}$ transported through the membrane is oxidized at the membrane surface, Fick's first law of diffusion can be simplified and used to calculate ' $D$ ',

$$
J_{\mathrm{SO}_{2}}=\frac{D C_{0}}{L}
$$

where ' $C_{0}$ ' is the bulk concentration of $\mathrm{SO}_{2}$ (estimated value $1.09 \mathrm{M}$ in 30 wt. $\% \mathrm{H}_{2} \mathrm{SO}_{4}$ and $0.9523 \mathrm{M}$ in $50 \mathrm{wt} . \% \mathrm{H}_{2} \mathrm{SO}_{4}$ ) and ' $L$ ' is the thickness of the membrane.

Table 3 shows the transport coefficient for all of the tested membranes. The commercial membranes were tested at two different acid concentrations, 30 and 50 wt.\% $\mathrm{H}_{2} \mathrm{SO}_{4}$. By increasing the sulfuric acid concentration the transport coefficient was reduced by a factor between 2 to 5 times. The new experimental membranes showed decrease in the transport coefficient, were the SDAPP showed similar values to PBI membranes and the platinized Nafion ${ }^{\circledR} 117$ showed a reduction by a factor of three of what is expected for an un-modified Nafion ${ }^{\circledR} 117$. The overall performance of the experimental membranes in comparison to PFSA membranes is remarkable. 
Table 3: $\mathrm{SO}_{2}$ transport coefficient through the tested membranes immersed in 30 wt.\% and 50 wt.\% $\mathrm{H}_{2} \mathrm{SO}_{4}$ saturated with $\mathrm{SO}_{2}$ at room temperature. Working electrode set at $1040 \mathrm{mV}$ vs. SHE.

\begin{tabular}{ccc}
\hline \hline & \multicolumn{2}{c}{ Transport Coefficient $\left(\mathbf{c m}^{\mathbf{2}} / \mathbf{s}\right)$} \\
Membrane & $\mathbf{3 0}$ wt. $\% \mathbf{H}_{\mathbf{2}} \mathbf{S O}_{\mathbf{4}}$ & $\mathbf{5 0}$ wt. $\mathbf{\%}_{\mathbf{2}} \mathbf{H O}_{\mathbf{4}}$ \\
\hline \hline Nafion ${ }^{\circledR}(\mathrm{EW}$ 1100) & $9.33 \mathrm{E}-7$ & $9.33 \mathrm{E}-7$ \\
\hline F-1460 & $4.45 \mathrm{E}-7$ & $1.67 \mathrm{E}-7$ \\
\hline Celtec-V & $6.76 \mathrm{E}-7$ & $3.44 \mathrm{E}-7$ \\
\hline Celtec-L & $7.24 \mathrm{E}-7$ & $2.30 \mathrm{E}-8$ \\
\hline OXPEKK & $5.28 \mathrm{E}-8$ & $2.46 \mathrm{E}-8$ \\
\hline FKB & $1.61 \mathrm{E}-7$ & $2.94 \mathrm{E}-8$ \\
\hline E-750 & $3.03 \mathrm{E}-7$ & $5.77 \mathrm{E}-8$ \\
\hline SDAPP-2.2 & $3.85 \mathrm{E}-7$ & ----- \\
\hline SDAPP-1t & $3.68 \mathrm{E}-7$ & ----- \\
\hline SDAPP-4t & $1.11 \mathrm{E}-7$ & ----- \\
\hline SDAPP-1.6 & $2.79 \mathrm{E}-7$ & ----- \\
\hline Platinized & $2.71 \mathrm{E}-7$ & --- \\
\hline Nafion ${ }^{\circledR} 117$ & & \\
\hline \hline
\end{tabular}

\subsection{SULFUR DIOXIDE TRANSPORT UNDER APPLIED POTENTIAL}

During normal electrolyzer operation water is dragged along with the protons across the membrane by what is termed electro-osmotic drag. Uncharged molecules are also subject to be drag across the membrane as well. In an attempt to quantify the effect of proton transport through the membrane on the $\mathrm{SO}_{2}$ transport, the permeation cell was modified in order to accommodate a two electrode configuration. Figure 6 shows the typical behavior of $\mathrm{SO}_{2}$ transport observed when an applied current is set across the membrane immersed in $30 \mathrm{wt} \%$ $\mathrm{H}_{2} \mathrm{SO}_{4}$ saturated with $\mathrm{SO}_{2}$ at room temperature. During the experiment, $\mathrm{SO}_{2}$ transport initially occurs by diffusion in the absence of polarization. Once the oxidation current reaches steady state, the cell is polarized passing a current of $0.2 \mathrm{~A}$.

The initial response of the system is an almost instantaneous spike increase in the $\mathrm{SO}_{2}$ flux. After the initial spike, the current starts to decline. This would be expected since the applied current is in fact consuming most of the $\mathrm{SO}_{2}$ dissolved in solution, and, therefore reducing the $\mathrm{SO}_{2}$ concentration on the bulk solution available for transport across the membrane. After several minutes, the current is discontinued and the system is allowed to relax until it 
reaches steady state conditions again. After a few more minutes, the second set of electrodes were disconnected.

From the initial spike in current it appears that polarization does affect the $\mathrm{SO}_{2}$ transport. However the observed spike may be a response of the primary potentiostat with the second electrode system. Thus, we cannot quantify the effect of polarization on $\mathrm{SO}_{2}$ transport at this time. We plan to modify the design of the permeation cell to isolate any electrical responses between the potentiostats.

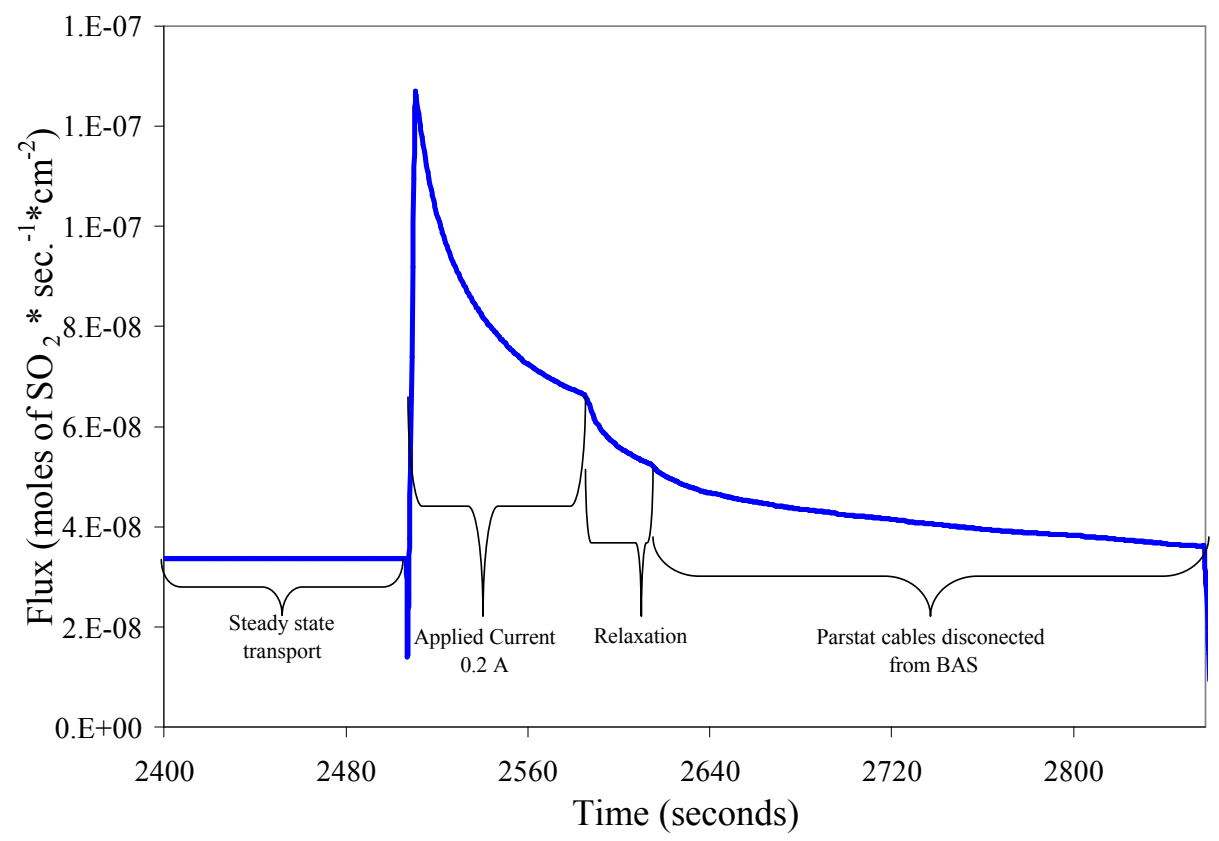

Figure 6: Typical behavior representing the effect of an applied current across the membrane on the $\mathrm{SO}_{2}$ transport through a cationic membrane immersed in $30 \mathrm{wt} \% \mathrm{H}_{2} \mathrm{SO}_{4}$ saturated with $\mathrm{SO}_{2}$ at room temperature. Working electrode set at $1040 \mathrm{mV}$ vs. SHE

\subsection{IN-PLANE IONIC CONDUCTIVITY}

Through-plane conductivity is the measurement of interest in an operating electrolyzer. However in order to obtain a good through-plane plane conductivity, the membrane must be assemble in membrane electrode assemblies (MEAs). In-plane conductivity has many advantages over through-plane conductivity, such as not requiring the preparation of a MEA. However, in some cases the conductivity measurement obtained by the in-plane measurement can differ from the through plane due to surface conduction. In the case where the samples are exposed to high concentrations of sulfuric acid, the risk of measuring surface conductivity of the membrane increases due to the fact that liquid electrolytes have better conductivity than solid conductors. In our system the amount of samples with different chemistries, makes it close to impossible to prepare MEAs in order to measure the through- 
plane conductivity in a timely manner. As a result, the use of in-plane conductivity will be used as a tool to qualitatively analyze the membrane conductivity.

In order to produce hydrogen in the most efficient way, a membrane with high proton conductivity is required, which will result in a reduction of IR losses across the cell. The inplane ionic resistance was calculated from [eq1] and plotted in Figure 7 in terms of proton conductivity for each membrane as a function of acid concentration and temperature. As seen in the plots, the conductivity is directly proportional to temperature. Also, we observed an increase in the conductivity when the membrane is contacted with $30 \mathrm{wt} \%$ sulfuric acid compared to that in water. In general, samples with a high degree of sulfonation (e.g., SDAPP-2.2, OXPEKK, PN117 and N112) exhibited very high conductivity. Note that the SPEK membrane from Fumatech, E-750, showed good conductivity in water, however it quickly degraded when exposed to high sulfuric acid concentrations.

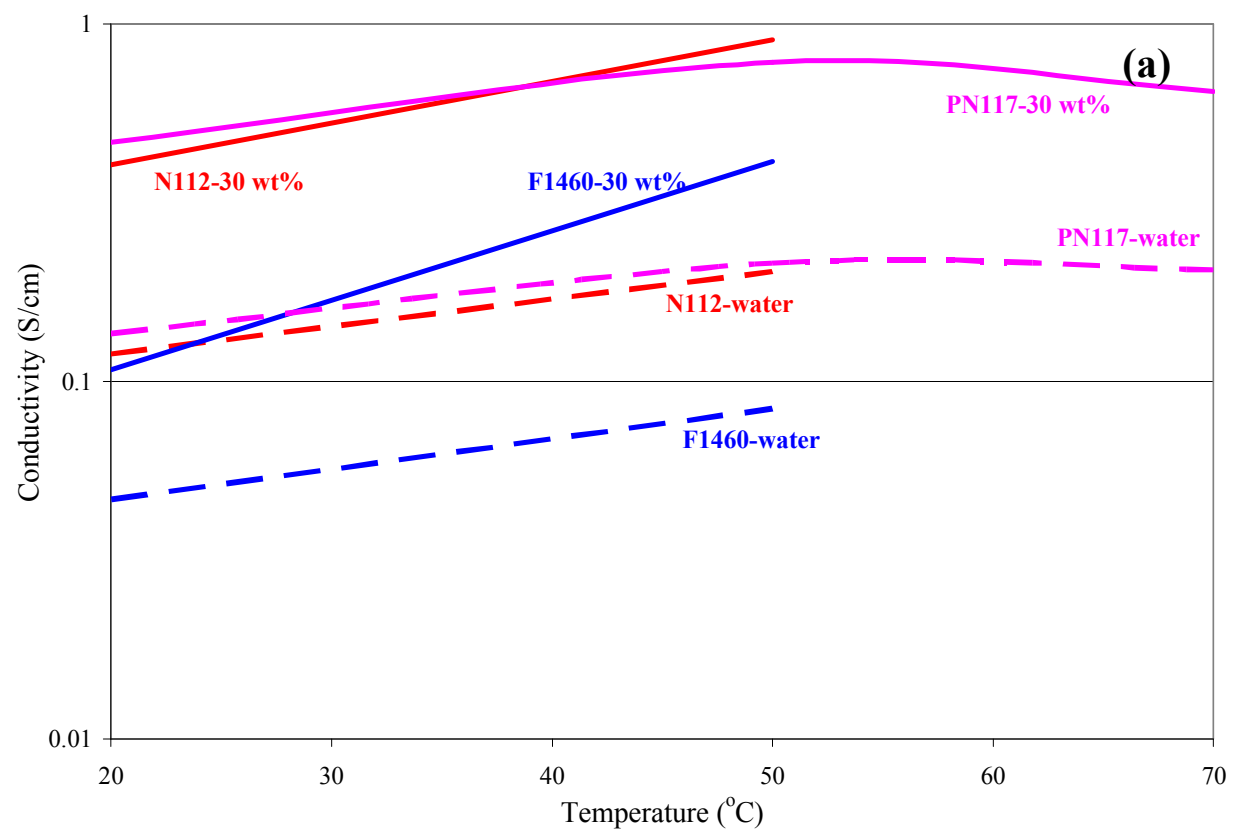




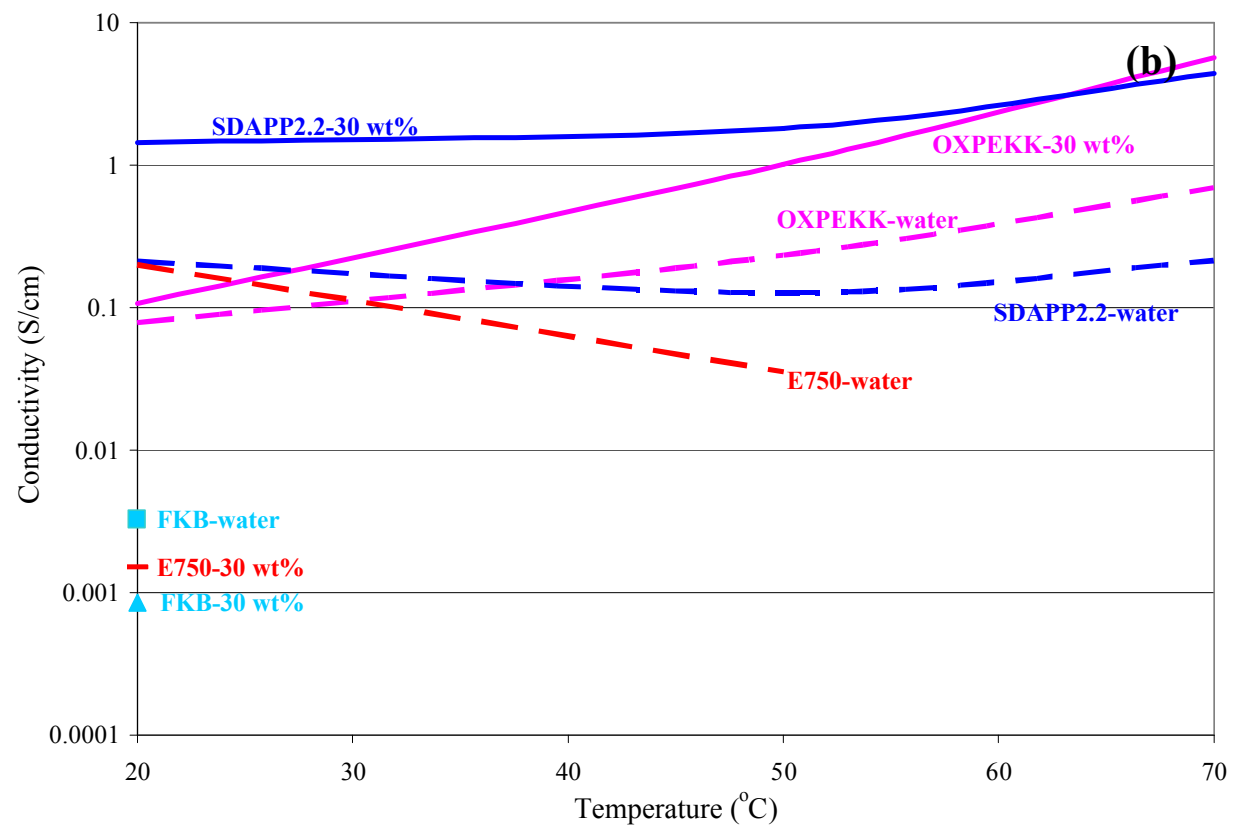

Figure 7: Ion conductivity of the membrane samples as a function of temperature and acid concentration for (a) fluorocarbon type membranes and (b) hydrocarbon type membranes. 


\subsection{CONCLUSIONS AND RECOMMENDATIONS}

The $\mathrm{SO}_{2}$ transport at two acid concentrations was studied on commercially available and experimental cationic membranes used mainly in low temperature fuel cells. It is desired for the SDE to have a membrane with a low diffusion coefficient, but high proton conductivity. The experimental membranes form the SDAPP showed a comparable transport coefficient to for $\mathrm{SO}_{2}$ to the PBI type membranes. However, these membranes are expected to have comparable conductivity to PFSA membranes. The incorporation of $\mathrm{Pt}$ nano-particles in the PFSA membranes showed a decrease of a factor of three. This method shows a promising method that can easily be adapted to modify other type membranes, such as SDAPP, in order to meet the SDE performance targets (1 Ton of S per 100 Tons of $\mathrm{H}_{2}$ ) without the lost of ionic conductivity.

Due to the limited amount of data regarding chemical and mechanical stability of the experimental membranes at high temperatures and acid concentrations, and the difficulty in preparing good MEAs with the hydrocarbon membranes; the use of PFSA membranes such as Nafion ${ }^{\circledR}$ with EW 1100 is recommended for the present SDE testing. To meet the SDE targets, continuation of the development of composite membranes by incorporating metal

particles or by forming multilayers between PFSA and hydrocarbon membranes will provide methods that will meet the SDE targets while decreasing membrane resistance and electrode contact resistance due to catalyst layer delamination. 


\section{0 REFERENCES}

[1] P. Sivasubramanian, R. P. Ramasamy, F. J. Freire, C. E. Holland and J. W. Weidner, "Electrochemical Hydrogen Production from Thermochemical Cycles using a Proton Exchange Membrane Electrolyzer", Int. J. Hydrogen Energy, submitted.

[2] Westinghouse Electric Corporation, "A Study on the Electrolysis of Sulfur Dioxide and Water for the Sulfur Cycle Hydrogen Production Process", AESD-TME-3043, July 1980.

[3] J. L. Steimke and T. J. Steeper, "Characterization Testing of $\mathrm{H}_{2} \mathrm{O}-\mathrm{SO}_{2}$ Electrolyzer at Ambient Pressure", Westinghouse Savannah River Company, Technical Report WSRC-TR2005-00310, August 1, 2005.

[4] H. L. Tang, M. Pan, S. P. Jiang and R. Z. Yuan, "Modification of NafionTM membrane to reduce methanol crossover via self-assembled Pd nanoparticles"', Materials Letters, 2005 (59), pp.3766-3770.

[5] R. Junginger and B. D. Struck, "Separators for the electrolytic cell of the sulfuric acid hybrid cycle", Int. J. Hydrogen Energy, 1982 (7), pp. 331-340.

[6] C. H. Fujimoto, M. A. Hickner, C. J. Cornelius and D. A. Loy, "Ionomeric Poly(phenylene) Prepared by Diels-Alder Polymerization: Synthesis and Physical Properties of a Novel Polyelectrolyte", Macromolecules, 2005 (38), pp. 5010-5016. 